\title{
Down from the Pedestal: Revisiting the Exploit of Literature in EFL Language Classes
}

\author{
Atefeh Rezanejad (Corresponding author) \\ Allameh Tabataba'i University, Tehran, Iran \\ E-mail: rezanejad_a85@yahoo.com \\ Zahra Lari \\ Sharif University of Technology, Tehran, Iran \\ E-mail:lari59z@yahoo.com \\ Zahra Mosalli \\ Urmia University, Urmia, Iran \\ E-mail:z.mosalli@gmail.com
}

Received: 25-08-2014

Accepted: 28-10-2014

Published: 01-03-2015

doi:10.7575/aiac.ijalel.v.4n.2p.158

URL: http://dx.doi.org/10.7575/aiac.ijalel.v.4n.2p.158

\begin{abstract}
According to Arthur (2006, p. 200), "Through the use of literature, a language learning experience might become at the same time a source of immediate pleasure and satisfaction for the student. This possibility makes literature an appealing teaching device for ESL teachers". However, numerous factors may contribute to the teachers' lack of interest in using literary texts as a teaching tool. This study was an attempt to investigate Iranian EFL teachers' attitude toward using literature in language classes and their perception toward the probable reasons of some teachers' lack of interest in doing so. Altogether forty-four language teachers (19 females and 25 males, with a mean age of 26) participated in this study. The data was collected through a validated and piloted questionnaire prepared by the researchers themselves (Cronbach's Alpha $=0.8$ ). The results of the study indicated that more than anything else, the participants thought that the main factor which hampers the effective use of literature in language classes is related to the outcome perception on the side of the students. The EFL teachers in this study thought that we as language teachers need to raise the language learners' awareness toward the benefits and advantages of literature in language classes. The findings of study may hold precious implications for language teachers. Moreover, EFL teachers may benefit from some guidelines and suggestions by the authors presented at the end of the paper.
\end{abstract}

Key words: Literature; EFL classes; Language Instruction; Survey

\section{Introduction}

Language learning is not an easy task and usually is not easily accomplished. Language learners have a lot to learn from vocabularies, structures, learning techniques, and so on. Hence, Teachers should employ various tools to help their students in the learning process. One of these tools is teaching materials that have great effects on FL teaching and hence teachers should adopt different materials to improve their teaching (Aghagolzadeh, \& Tajabadi, 2012).

Literature is one of the teaching materials that can help students in the foreign language learning process. Literary works can be regarded as a source of additional practice. They can provide students with lessons on grammar, vocabulary and other kinds of linguistic exercises. Hence, literature can help students in the language learning process and help them enhance their general linguistic knowledge (Shazu, 2014).

Apart from achieving general language proficiency, students should learn how to use language which is one the various purposes of learning language (Daskalovska \& Dimova, 2012). They should learn how to use language in different locations such as school, home, how to communicate with different occupational groups, for instance doctors, teachers and they should learn how to use language in different geographical regions. Literature is a tool that can help students to learn how to use language and how to use it differently. It can act as a source of sociolinguistic richness. By providing students with different varieties of language like sociolects, regional dialects, jargon, etc., literature helps them develop their sociolinguistic competence and learn how to communicate differently in diverse occasions and with different people (Hismanoglu, 2005).

All in all, it seems that literature has an undisputable effect on the teaching process (Khatib \& Shakouri, 2012). It provides teachers with the chance of a better teaching and students with enhancing their linguistic and communicative abilities (Hussein, 2007). However, since different processes are at work in different places and cultures to teach language, it is the teacher who decide whether to include the literature in the syllabus or not and $\mathrm{s} / \mathrm{he}$ will choose the literary text, activities and the purpose for including the text (Shazu, 2014). The present research was concerned with the attitude of Iranian EFL teachers toward the use of literature in language classes. 


\section{Review of the Literature}

Theories are powerful forces that influence what we do and how we do it and they also have great effects on our teaching in general and teaching literature in particular (Beach, Appleman, Hynds, \& Wilhelm, 2011). According to Showalter (2003, cited in Mohammed, 2014), for a successful literature teaching you should first determine what do you want your students to learn and then decide on an approach that can help them to learn.

\subsection{Why Literature?}

Literature is viewed as an effective tool in the language learning process and many authors have suggested different reasons in favor of using literature in language classroom (Khati, Rezaei,\& Derakhshan, 2011). These reasons can be generally divided into linguistic reasons, methodological reasons and motivational reasons (Duff \& Maley, 2007; Maley, 2001; Pison, 2000). However, the advantages of literature to the language classroom are not limited to these three mentioned reasons. For instance Collie and Slater (1990, cited in Hismanoglu, 2005) suggested the use of literature in the language classroom because of the following reasons: valuable authentic material, cultural enrichment, language enrichment and personal involvement.

Literatrary works are authentic materials which are not created for pedagogical purposes. They act as a complement course material and expose students to real life language. Literature helps learners to understand how to communicate verbally and nonverbally - in the country where the language is spoken and is a tool that helps them to understand that country. Moreover, literature increases cultural grammar of language learner. As learners read a substantial body of contextualized texts, they are exposed to a wide range of lexical and syntactic items and learn about the syntax and structure of sentences, and learn how to write cohesively. Hence, their communicative and cultural competence as well as their linguistic competence will be improved. In addition, because of the personal involvement that literature creates in language learners, it can help them in the language learning process. As they read a text, they are drawn to the text and understanding the text doesn't matter to them. They follow the event of the story and want to know what will happen. They feel close to some characters and share feelings with them and hence, literature is useful for the whole language learning process Collie and Slater (1990, cited in Hismanoglu, 2005).

Hirvela (2001, cited in Tasneen, 2010) also stated some of the advantages of using literature in EFL classes which include: 1) more active role on the part of learners while learning through literature 2) providing students with creative activities such as solving mysteries that foster deeper connections. 3) Exposing students to different kind of texts and teach the language 4) exposing students to various cultures and styles of the language. And 5) fostering students' academic literary skills via imaginative property of texts. Using literary works in the language classes can also be justified on the grounds that they are motivating materials that can foster Emotional intelligence, and improve critical thinking of students. They are also great mediums for intensive and extensive reading and enhancing critical thinking in students (Khatib, Rezaee, \& Derakhshan, 2011). And last but not least, literature helps to make autonomous learners who can continue learning language after completing their formal education (Daskalovska, \& Dimova, (2012). At the end, it should be mentioned that despite all the advantages of literature, teachers should be careful in selecting texts and adapting an appropriate model for teaching based on the needs of their learners.

\subsection{Different models of teaching literature}

There are various models that have been proposed for teaching literature. Here we will mention the models recommended by van (2009) and Fernandes and Alsaeed (2014).

\subsubsection{Models of teaching literature by Van (2009)}

1) New Criticism: Based on this model, meaning is not influenced by external factors or readers' intention and can be interpreted from the text itself. Hence, the readers are required to understand the text by careful reading of it.

2) Structuralism: This approach is focused on linguistic aspects of a text. It will not accept subjective interpretation of the texts and readers' individual responses are ignored. They should use their linguistic knowledge such as knowledge of structure and put the text into a hierarchical system.

3) Stylistics: It puts emphasis on readers' role in the reading process. Readers are encouraged to use their linguistic knowledge to interpret the texts. Comparative model of Widdowson (1983, cited in van, 2009) is a useful model of this approach which requires the students to compare literary texts with other kind of texts and hence learn how to use language variously to get things done.

4) Reader - response: Readers' personal experiences, feelings and opinions are emphasized in this approach. It resembles the top-down process of reading that focuses on the interrelationship between reader and the text. Since different readers have various experiences and feeling, the authors intention of the text is described in various ways.

5) Language based: Linguistic knowledge of students is emphasized in this approach again. The students are provided with activities that activate their background knowledge and promote their vocabulary knowledge and reading comprehension. The teachers' role is to provide appropriate classroom activities.

6) Critical literacy: This approach identifies the interrelationship between language use and social power. It helps students to promote their critical awareness. They will understand how language shapes social relations and how social and political factors shape language. 
1) Cultural model: It is a teacher-centered model that focuses on the social and political aspects of a literary text. It can be associated to classical methods that are applied in universities.

2) Language model: As opposed to the cultural model, the language model is a learner centered approach. As learners read a text, they focus on language usage to understand it. Teachers influenced by this model can focus on linguistic aspects of texts such as grammar and vocabulary to help learners to promote their reading and studying abilities.

3) The personal growth model: This is also a learner centered model which is process oriented. Learners are required to reveal their personal views, thoughts and experiences. They should have interaction with the text they are provided with in order to make language unforgettable.

\subsection{Criteria for selecting literary texts}

"English literature has not been considered a useful teaching tool in the EFL classrooms of many non-English speaking countries. This is because teaching L2 largely has been regarded as a matter of linguistics" (Alemi, 2011, p. 177). Nevertheless, according to Bagherkazemi \& Alemi (2010, p. 11) "EFL material developers, syllabus designers and teachers should select the most appropriate approach or combination of approaches, design activities and tasks and make the most out of literature to enhance language learning and teaching by analyzing the idiosyncratic features of the classroom, educational system and culture in which they will be used". According to Makay (1982), successful teaching of literature depends on the works that are selected. If the texts are to promote language learning, they should be chosen carefully based on students' needs and interests and match their psychological development Sell, J. (200). Reading such texts is not only a tedious task for students but it also brings about the enjoyment and satisfaction (Daskalovska, \& Dimova, (2012).

One of the first factors that literature teachers should consider when selecting a text, is the difficulty level of that text. Teachers should choose texts that their vocabulary and structure match their students' language level, since easy texts facilitates students' comprehension of the text (Hismanoglu, 2005). Another factor is students cultural familiarity with the text. The teacher should choose the text based on students' cultural background; otherwise they remain on him/her to understand the text (van, 2009). Another aspect that teachers should bear in mind is that of meaningfulness and amusement. The texts that enjoy these qualities can have long-term effects on students' linguistic and extra linguistic knowledge (Hismanoglu, 2005). Other factors that worth considering in choosing literary texts are that of students' needs and interest.The literary texts should have the ability to create personal involvement in students by arousing their interest and creating positive attitudes in them (Hismanoglu, 2005). In addition, pleasure that students find in reading literature helps them to overcome the linguistic obstacles they may find in less involving text (Collie and Slater 1990:6-7, cited in Hismanoglu, 2005).

\subsection{Previous studies on the use of literature in language classes}

Several studies addressed the issues of literature and foreign language teaching from different perspectives such as learning and teaching literature via internet (Arikan, 2008; Kartal, \& Arikan, 2010), investing its effects on enhancing students motivation (Vural, 2013) and prospective teachers views regarding literature based courses (Zorba, Arikan, \& Caner, 2013). Here we will consider some of these studies.

In order to develop teaching literature in language classes in turkey, Küçükoğlu and Arikan (2011) investigated the views of 84 prospective English teachers about literature and its place in their teacher education program. The participants were administered a questionnaire that studied their views on literature, having literature in teacher education program and using literature at all levels of English classes. The findings showed that $78 \%$ of prospective teachers had positive attitude toward literature and about $74 \%$ of them thought that literature can help them to learn the target culture better. As far as literary genres are concerned, it was found that about $85 \%$ of participants mentioned that basic genres like poetry, novel and short stories are useful for learners. About using literature in language classes about $81 \%$ of participants stated that literature can be motivating for students. They also mentioned that literature can be useful in teaching reading, writing vocabulary and grammar. However, they agreed that it cannot be of any help in teaching speaking and listening.

In another study, Tanseen (2010) investigated teachers' and students' views regarding the use of literature - both capital and small 1- at international school in Bangkok. They also examined the correspondence between their views and classroom activities and the kind of literary texts that teachers prefer. To that end, three instruments including a questionnaire, classroom observation and an interview were used. It was found that both the teachers (74\%) and students $(98 \%)$ we agreed and strongly agreed that literature can be a useful asset to use in the language classroom. Regarding the type of texts it was found that $50 \%$ of teachers preferred short stories and $25 \%$ of them preferred poems and plays to use in their classroom. What's more, none of the teachers chose literary texts such as novel for use in the classroom. Regarding the capital and small 1 , students commented that small 1 literature can be of more help, because it is usually shorter and easier and hence takes less time to read. In addition it is more creative and helps them to think more.

In an attempt to see the effects of group discussion in literature courses on students advanced level speaking functions, Donato and Brooks (2004), set out a study to investigate a literature course for Spanish language majors. For the sake of this study the class discourse was analyzed to see if class discussions could help students to elaborate, narrate, hypothesize, describe, argue points, and defend opinions. Moreover, the teacher and students were interviewed regarding the course goals and their perception of literature in the class. The findings showed that the discourse pattern prevented students to move beyond word and sentence level utterances. It was concluded that having group discussion 
or asking about student opinions does guarantee their advanced level language usage. What is more important is the integration of various interactional patterns in literature classes and teachers and students awareness of literature as a source that can help students to promote their speaking abilities.

As was mentioned it is the teacher who decides whether to include literature in the syllabus or not (Shazu, 2014) and different teachers have different attitudes towards literature. Some of the teachers focus on linguistic benefits of teaching language and some of them who integrate literature believe that it can help students to learn language more effectively (Erkaya, 2005). Hence, this study was an attempt to investigate Iranian EFL teachers' attitudes regarding the use of literature in language classes.

- What factors do Iranian EFL teachers consider significant in the extension of utilization of literature in language classes?

\section{Methodology}

\subsection{Participants}

Overall, forty-four students of language studies (19 females and 25 males) from different fields of studies (Linguistics, TEFL, Translation, and Literature) and various university degrees $(\mathrm{BA}=6, \mathrm{MA}=27, \& \mathrm{PhD}=11)$ participated in this study. The mean age of the respondents was 26 , with a minimum age of 21 and a maximum age of 34 . In addition, they had different teaching experiences ranging from 1-5 years (22 teachers), 6-10 years (16 teachers), and +11 years (6 teachers). The participants taught English as a foreign language to Iranian EFL learners in different institutes found in different cities (e.g. Tehran, Karaj, Urmia, Yazd, Sari, Shiraz, Kerman ...) in Iran.

\subsection{Instrument}

In order to collect the data for the present study, a questionnaire was developed by the researchers themselves (Appendix 1). As the first step in the development of the survey, the literature on the use of literature in language classes was reviewed. That way we could come up with the basic points and elements to be included in the survey. The survey was then refined and rephrased for more than five times and discussed over in the research group. After finalizing the first draft of the survey, it was piloted with thirty participants similar to the main participants of the study. The Cronbach's Alpha of 0.8 was calculated for the survey which is an indicator of a good reliability.

\subsection{Data Collection Procedure}

All questionnaires were collected on-line and through the respondents' email. That way we could facilitate the process of data collection from different cities in Iran. The participants were selected based on their willingness to contribute and also their availability. To boost up the process of data collection, the participants were kindly asked to send the survey to their friends who teach English.

\section{Results and Discussion}

As our main research question in this study, we were about to figure out Iranian EFL teachers' attitude toward the factors affecting their willingness to use literature in their language classes. In order to answer this question, 37 items in a survey was proposed to the participants. The items were categorized under seven major categories (Table 1). The categories represented the main probable reasons for lack of teachers' interest in using literature as a teaching device in language classes.

As indicated in Table 1, the first element "Outcome Perception" received the highest mean rating from the participants. A mean rating of $4.62(\mathrm{Min}=2.5, \mathrm{Max}=6, \mathrm{SD}=.94)$ was allocated to this item. This element refers to the language students' scholastic understandings, perceptions, and attitudes toward use of literature in language learning. It is mainly concerned with their awareness regarding the benefits and outcomes of studying literary texts in order to enhance learners' general English knowledge. The second most appreciated item was "The Teachers" with a mean rating of 4.20 $(\operatorname{Min}=2.50, \operatorname{Max}=5.33, \mathrm{SD}=.76)$. That is to say, many participants thought that one of the major reasons for not appreciating literature in language classes goes back to the teachers themselves. To put it another way, language teachers may not be that aware of the positive points attached to application of literature in order to enhance the students' language knowledge.

Table 1. Descriptive statistics for factors affecting use of literature in language classes

\begin{tabular}{llllll}
\hline & N & Min & Max & Mean & SD \\
\hline Outcome Perception & 44 & 2.50 & 6.00 & 4.62 & .94 \\
The Teachers & 44 & 2.50 & 5.33 & 4.20 & .76 \\
Instructional Issues & 44 & 3.20 & 5.40 & 4.02 & .66 \\
The Students & 44 & 2.80 & 5.00 & 3.80 & .48 \\
L1 Literature & 44 & 1.67 & 5.33 & 3.59 & .84 \\
Secondary Features & 44 & 1.75 & 5.25 & 3.38 & .88 \\
Affective Considerations & 44 & 1.60 & 4.40 & 3.36 & .67 \\
\hline
\end{tabular}


Next, came the factor of "Instructional Issues" with a mean rating score of 4.02 (Min $=3.20, \mathrm{Max}=5.40, \mathrm{SD}=.66)$. This element referred to some details in the process of instruction such as educational policies of language schools, salaries, time, and main teaching materials. It goes without saying that these issues can greatly influence the teaching atmosphere. Subsequently, a mean rating of $3.80(\mathrm{Min}=2.80, \mathrm{Max}=5, \mathrm{SD}=.48)$ was allocated to the fourth factor, namely "The Students". This element indeed considered the students themselves as the major influential element in determining the success of using literary texts as a teaching source. The facet "L1 Literature" received a mean rating score of $3.59(\mathrm{Min}=1.65, \mathrm{Max}=5.33, \mathrm{SD}=.84)$. It was concerned with the role of L1 literature of the students and their attitude toward to it and its impact on the learners' attitude toward L2 literature.

In addition, the component "Secondary Features" received a mean rating score of $3.38($ Min $=1.75, \mathrm{Max}=5.25, \mathrm{SD}=$ .88 ). These features relate to such facts as the price of literary books, their appearance, and appropriacy regarding the learners' age and proficiency level. As a final point, a mean rating of 3.36 ( Min = 1.60, $\mathrm{Max}=4.40, \mathrm{SD}=.67$ ) was allocated to the seventh factor, namely "Affective Consideration". This aspect encompassed issues related to emotional side of literature pedagogy and the attitude and feeling of language students toward studying literature in their language classes.

In this section a detailed report on all specific items of the survey included in the survey will be presented. The results over the items will appear in the order they appeared in the actual survey given to the respondents. That is to say the number for items represents the actual number of the item in the survey. As indicated in Table 2, the first category presented to the respondents entailed items related to the students' L1 literature. This section of the survey comprised of six items and delved into various issues concerning L1 literature. As illustrated in Table 2, the last item received the highest mean rating score (Mean $=4, \mathrm{SD}=1.20$ ). This item implied that most Iranian families usually don't pay the deserved attention to literature and this may affect the language students' attitude toward L2 literature.

Table 2. Descriptive statistics for items of survey under the category of "L1 Literature"

\begin{tabular}{lccccc}
\hline & N & Min & Max & Mean & SD \\
\hline $\begin{array}{l}\text { 1. Most Iranian students don't enjoy reading the literature even } \\
\text { in their L1. }\end{array}$ & 44 & 2 & 6 & 3.55 & 1.08 \\
2. Most Iranian students don't know any of the poets and writers & 44 & 1 & 6 & 3.32 & 1.21 \\
of their own culture. & & & & & \\
3. Most Iranian students can't recite some lines even from their & 44 & 1 & 6 & 3.98 & 1.37 \\
L1 literature. & & & & \\
4. Most Iranian students don't have any good memories of their & 44 & 1 & 5 & 3.45 & 1.02 \\
L1 literature classes and never wish to go back to them. \\
$\begin{array}{l}\text { 5. Our L1 Persian literature is not welcomed much by our } \\
\text { students. }\end{array}$ \\
$\begin{array}{l}\text { 6. Iranian families usually don't pay much attention to Persian } \\
\text { literature. }\end{array}$ & 44 & 2 & 5 & 3.25 & .94 \\
\hline
\end{tabular}

Next were items seven to twelve which were related to the role of the language learners' awareness of the pedagogical significance of studying literary texts in order to enhance one's language knowledge. Interestingly item 10 received the highest mean score. A mean rating score of $5.05(\mathrm{SD}=1.03)$ was allocated to this item. Most of the respondents thought that "No one has ever talked to most Iranian students on the use of reading literature". This again calls for more attention to the leading role of awareness raising in pedagogy. It is assumed that if we make the learners aware of the real efficacy and importance of the pedagogical system, this will raise their awareness and later lead to better and more successful learning.

Table 3. Descriptive statistics for items of survey under the category of "Outcome Perception"

\begin{tabular}{|c|c|c|c|c|c|}
\hline & $\mathbf{N}$ & Min & Max & Mean & SD \\
\hline $\begin{array}{l}\text { 7. Most Iranian students don't even exactly know why they } \\
\text { should read literature. }\end{array}$ & 44 & 2 & 6 & 4.64 & 1.16 \\
\hline $\begin{array}{l}\text { 8. Most Iranian students think reading literature has no benefit } \\
\text { for them. }\end{array}$ & 44 & 2 & 6 & 4.36 & 1.46 \\
\hline $\begin{array}{l}\text { 9. Most Iranian students think that they may never be able to use } \\
\text { literature in their future life. }\end{array}$ & 44 & 2 & 6 & 4.73 & 1.14 \\
\hline $\begin{array}{l}10 . \text { No one has ever talked to most Iranian students on the use of } \\
\text { reading literature. }\end{array}$ & 44 & 2 & 6 & 5.05 & 1.03 \\
\hline $\begin{array}{l}\text { 11. Most Iranian students think that they have more important } \\
\text { things to read than literature. }\end{array}$ & 44 & 2 & 6 & 4.82 & 1.16 \\
\hline $\begin{array}{l}\text { 12. Most Iranian students can never find any positive point in } \\
\text { reading literature, whether in Persian or English. }\end{array}$ & 44 & 1 & 6 & 4.16 & 1.49 \\
\hline
\end{tabular}


The next four items on the survey (items 13 to 16) pertained to the secondary features attributed to reading literary texts. To mention some examples we can name the price of literary texts such as short stories and novels, the appearance of the literature books and their attractions, and appealing content of literary texts. As depicted in Table 4, item 16 received the highest mean rating score (Mean $=4.09, \mathrm{SD}=1.32$ ). The item said: "I think some learners don't enjoy literature because the texts are not adapted to their age and proficiency level" and in fact referred to the significance of choosing literary texts based on valid and reliable criteria to fit the age, proficiency level, gender, and interest of the learners.

Table 4. Descriptive statistics for items of survey under the category of "Secondary features"

\begin{tabular}{|c|c|c|c|c|c|}
\hline & $\mathbf{N}$ & Min & $\operatorname{Max}$ & Mean & SD \\
\hline $\begin{array}{l}\text { 13. Most Iranian students don't read much English poems or } \\
\text { storybooks because the English books are very expensive. }\end{array}$ & 44 & 1 & 5 & 3.14 & 1.09 \\
\hline $\begin{array}{l}\text { 14. Most Iranian students don't enjoy reading English literature } \\
\text { because they don't like the appearance of the books and their } \\
\text { paper qualities. }\end{array}$ & 44 & 1 & 6 & 2.70 & 1.06 \\
\hline $\begin{array}{l}\text { 15. Most Iranian students prefer books coming with audio CDs. } \\
\text { If they don't have CDs, they may not be interested to buy them. }\end{array}$ & 44 & 1 & 6 & 3.61 & 1.24 \\
\hline $\begin{array}{l}\text { 16. I think some learners don't enjoy literature because the texts } \\
\text { are not adapted to their age and proficiency level. }\end{array}$ & 44 & 1 & 6 & 4.09 & 1.32 \\
\hline
\end{tabular}

The category of "Affective Consideration" was dealt with in the next section of the survey. We had five items for this section (items 17 to 21). Table 5 summarizes the results for this section. As illustrated, items $21(\mathrm{Mean}=4.5$, SD $=$ $1.17)$ and 19 (Mean $=2.27, \mathrm{SD}=.99)$ were the most and least selected ones correspondingly. Majority of the language teachers thought that Iranian language students are not that much exposed to the literature in English. They considered it a matter of habit which needs more attention from teachers.

Table 5. Descriptive statistics for items of survey under the category of "Affective Considerations"

\begin{tabular}{|c|c|c|c|c|c|}
\hline & $\mathbf{N}$ & Min & Max & Mean & SD \\
\hline 17. Most Iranian students hate literature. & 44 & 1 & 5 & 3.05 & 1.18 \\
\hline $\begin{array}{l}\text { 18. Students may get stressed when reading an English poem or } \\
\text { story. }\end{array}$ & 44 & 1 & 4 & 2.75 & 1.01 \\
\hline $\begin{array}{l}\text { 19. Sometimes some students may feel depressed after reading } \\
\text { stories or poems, so they prefer not to read them. }\end{array}$ & 44 & 1 & 4 & 2.27 & .99 \\
\hline $\begin{array}{l}\text { 20. English literary texts are very difficult and complex for most } \\
\text { Iranian students and finding all those vocabulary is much tiring } \\
\text { and boring for them. }\end{array}$ & 44 & 2 & 6 & 4.25 & 1.12 \\
\hline $\begin{array}{l}\text { 21. It's just a matter of habit. I think the students are not much } \\
\text { interested in English literature as a source to improve their } \\
\text { English because their teachers never tried so and there was no } \\
\text { force on them. }\end{array}$ & 44 & 1 & 6 & 4.50 & 1.17 \\
\hline
\end{tabular}

Table 6 presents the results concerning the descriptive statistics for items of survey (items 22 to 27 ) under the category of "The Teachers". The participants in this part were asked about their attitude toward the role of the language teachers themselves in the extension of use of literary texts in promotion of language learners' knowledge. As depicted, item 22 (Mean $=5.07, \mathrm{SD}=.81$ ) received the highest mean rating score form the participants. Most of the respondents thought that the teachers' attitude toward literature can affect the students' view too. They assumed if teachers favor literature themselves, they would more able to encourage their students to read literature. Another interesting finding in this section was related to item 26 which received the lowest rating score (Mean $=3.64, \mathrm{SD}=1.25$ ). Very few teacher thought that Iranian EFL teachers hate literature and that seems to be a good news! 


\begin{tabular}{|c|c|c|c|c|c|}
\hline & $\mathbf{N}$ & Min & Max & Mean & SD \\
\hline $\begin{array}{l}\text { 22. I think the teachers' attitude toward literature has an } \\
\text { important effect on its range of application by the teachers. }\end{array}$ & 44 & 3 & 6 & 5.07 & .81 \\
\hline $\begin{array}{l}\text { 23. Most teachers think using literature in classes is just a waste } \\
\text { of time. }\end{array}$ & 44 & 1 & 6 & 3.86 & 1.53 \\
\hline $\begin{array}{l}\text { 24. In most teachers' opinion, the students may not benefit } \\
\text { much from reading literary works to improve their English. } \\
\text { 25. The reason why most teachers don't use literature in their }\end{array}$ & 44 & 1 & 6 & 3.75 & 1.27 \\
\hline $\begin{array}{l}\text { English classes is that they themselves don't know much about } \\
\text { the literature and English writers or poets. }\end{array}$ & 44 & 2 & 6 & 4.80 & .79 \\
\hline $\begin{array}{l}\text { 26. Teachers don't use literature in their language classes } \\
\text { because they may just hate literature. }\end{array}$ & 44 & 1 & 6 & 3.64 & 1.25 \\
\hline $\begin{array}{l}\text { 27. Some teachers don't use much literature in their classes } \\
\text { because they feel they're not that competent in general English } \\
\text { to teach it. }\end{array}$ & 44 & 1 & 6 & 4.11 & 1.08 \\
\hline
\end{tabular}

Another important factor in the extension of use of literary texts in language classes seems to be related to the students themselves. We gauged the language teachers' attitude toward this element in items 28 to 32 of the survey. With very little difference, items 30 and 31 were the most selected ones. They received a mean score of $4.09(\mathrm{SD}=.93)$ and 4.05 $(\mathrm{SD}=1.03)$ respectively. It appears that for the most part, teacher respondents thought that the language students usually don't hold positive attitudes toward literature and consider it a tough work to do. The respondents also believed that the students' cooperation in language classes is a crucial factor leading to success or failure of literature.

Table 7. Descriptive statistics for items of survey under the category of "The Students"

\begin{tabular}{|c|c|c|c|c|c|}
\hline & $\mathbf{N}$ & Min & Max & Mean & SD \\
\hline $\begin{array}{l}\text { 28. Most Iranian language teacher don't use much literature in } \\
\text { their classes because the students don't enjoy it much. }\end{array}$ & 44 & 2 & 5 & 3.73 & .81 \\
\hline $\begin{array}{l}\text { 29. One reason for teachers' lack of willingness to teach } \\
\text { literature in their language classes is the negative feedback they } \\
\text { receive from the learners. }\end{array}$ & 44 & 2 & 6 & 3.86 & 1.00 \\
\hline $\begin{array}{l}\text { 30. It seems that most students don't cooperate with teachers in } \\
\text { studying literature. }\end{array}$ & 44 & 2 & 6 & 4.09 & .93 \\
\hline $\begin{array}{l}\text { 31. Iranian language students think that reading literature in } \\
\text { language classes is a tough work. }\end{array}$ & 44 & 3 & 6 & 4.05 & 1.03 \\
\hline $\begin{array}{l}\text { 32. Language students don't have the required time to enhance } \\
\text { their general language skills through literature. }\end{array}$ & 44 & 1 & 5 & 3.32 & 1.34 \\
\hline
\end{tabular}

Finally, in the last section of the survey items under the category of "Instructional Issues" were presented to the participants. This phase contained five items (items 33 to 37) and was mostly concerned with issues mainly related to pedagogical policies of language institutes, time allocated to different teaching materials, salaries, and course syllabus. As depicted in Table 8, the most frequent item was item 37 with a mean score of $4.45(\mathrm{SD}=87)$. Most of the language teachers though that, Language teachers are usually required to focus on the main book to be taught in the course. It seems that majority of language teachers in Iranian language institutes don't have that much freedom in planning their courses, including choosing the type of course book or handouts.

Table 8. Descriptive statistics for items of survey under the category of "Instructional Issues"

\begin{tabular}{|c|c|c|c|c|c|}
\hline & $\mathbf{N}$ & Min & Max & Mean & SD \\
\hline $\begin{array}{l}\text { 33. The time of classes doesn't allow most teachers to take } \\
\text { advantage of literature in their language classes. }\end{array}$ & 44 & 1 & 6 & 4.00 & 1.49 \\
\hline $\begin{array}{l}\text { 34. Due to low salaries and other financial issues, most language } \\
\text { teachers are not much interested in teaching English literature in } \\
\text { their language classes. }\end{array}$ & 44 & 1 & 6 & 3.39 & 1.26 \\
\hline $\begin{array}{l}\text { 35. Most of the time, the limiting policies of the language } \\
\text { institutes don't allow teachers to be flexible in their syllabi and } \\
\text { use literature in their classes. }\end{array}$ & 44 & 1 & 6 & 4.39 & .99 \\
\hline $\begin{array}{l}\text { 36. Most language institutes prohibit teachers from using any } \\
\text { kind of handouts and this also includes using literature. }\end{array}$ & 44 & 1 & 6 & 3.91 & 1.23 \\
\hline $\begin{array}{l}\text { 37. Language teachers are usually required to focus on the main } \\
\text { book to be taught in the course. }\end{array}$ & 44 & 2 & 6 & 4.45 & .87 \\
\hline
\end{tabular}




\section{Conclusion}

The researchers' main purpose in this study was figuring out the probable factors affecting the Iranian EFL teachers' willingness to use literature as a language teaching device in language classes. From among the numerous sources which language teachers can utilize in order to assist the language learners, literature is regarded as one of the most fruitful and useful cases. Through the use of literature students would raise their knowledge regarding different aspects of the language. According to Carter and Long (1991), "using literature as a resource offers teachers possibilities for basing language learning activities on materials that can stimulate greater interest and involvement than is the case with other texts (p. 3).

As the results of the present study indicated, it was observed that in the participants' idea the main element to be considered in using literature in language classes is "outcome perception". To put it another way, the main point which was considered by the majority of the language teachers was concerned with raising awareness among the students. Language students need to be aware of the final outcome of the course and the benefits of studying literature in order to enhance their language knowledge.

As the researchers in this study strongly believe in the power of literature in making language learning a pleasant experience for the students and are concerned with raising the language learners' appreciation of literature and literary texts in language classes, some recommendations over the issue are presented below:

- There are numerous types of literary texts and each may be appropriate for diverse groups of language learners. Teachers need to be wary of these different types and select them based of the need of their class, age of the students, their gender, and also their proficiency level.

- Along with use of different literary texts, various teaching methods can also assist the process. Language teachers are supposed to select the most appropriate method which suits their language class and group of students.

- As many students are still not that much motivated to read literature, it is believed that we as teachers need to raise their motivation and encourage their appreciation of literary texts. This can be achieved through a number of strategies such as asking students to memorize poems, act out plays in class, or even writing their own poems and short stories.

\section{References}

Aghagolzadeh, F., \& Tajabadi, F. (2012). A Debate on literature as a teaching material in FLT. Journal of Language Teaching and Research, 3(1), 205-210.

Alemi, M. (2011). The use of literary works in an EFL class. Theory and Practice in Language Studies, 1(2), 177-180. doi:10.4304/tpls.1. 2 .1 77 - 180

Arikan, A. (2008). Using internet groups in the learning of literature. O.H.U. Journal of Education, 34, 19-26.

Arthur, B. (2006). Reading literature and learning a second language. Language Learning, $18(3$ \& 4), $199-210$.

Bagherkazemi, M., \& Alemi, M. (2010). Literature in the EFL/ESL classroom: Consensus and controversy. LIBRI, 1(1), $11-12$.

Beach, R., Appleman, D., Hynds, S., \& Wilhelm, J. (2011). Teaching literature to adolescents. New York, Routledge

Carter, R. \& Long, M. N. (1991). Teaching literature. London: Longman Group Ltd.

Daskalovska, N., \& Dimova, V. (2012). Why should literature be used in the language classroom? Procedia-Social and Behavioral Sciences, 46, 1182-1186.

Donato, R., \& Brooks, F. B. (2004). Literary discussions and advanced speaking functions: Researching the (dis)connection. Foreign Language Annals, 37, 183-199.

Duff, A. and Maley, A. (2007). Literature. (Second edition). Oxford: Oxford University Press.

Erkaya, O. R. (2005). Benefits of Using Short Stories in the EFL Context. Asian EFL Journal, 8, 1-13.

Fernanded, L. \& Alsaeed, N.H.Q. ( 2014). Using English literature for the teaching of English. International Journal of English Language and Literature Studies, 3(2), 126-133.

Hişmanoğlu, M. (2005). Teaching English through literature. Journal of Language and Linguistic Studies, 1(1), 53-66.

Hussein, N. (2007). Literature in language classroom: An inside view. Journal of State University of Bangladesh, 1(1), 113-120.

Kartal, E., \& Arikan, A. (2010). A Recommendation for a new internet-based environment for Studying Literature. USChina Education Review, 7(7), 93-99.

Khatib, M., Rezaei, S., \& Derakhshan, A. (2011). Literature in EFL/ESL classroom. English Language Teaching, 4(1), 201-208. 
Khatib, M., \& Shakouri, N. (2012). Literature stance in developing critical thinking: A pedagogical look. International Journal of Research Studies in Language Learning, 2(4), 101-108.

Küçükoğlu, H., \& Arikan, A. (2011). Prospective English language teachers' views on literature in their teacher education curriculum and its potential value. Procedia-Social and Behavioral Sciences, 15, 1718-1722.

Maley, A. (2001). Literature in the language classroom. In R. Carter and D. Nunan (Eds.), The Cambridge Guide to TESOL, (pp. 180-185). Cambridge: Cambridge University Press.

McKay, S. (1982). Literature in the ESL classroom. Tesol Quarterly, 16(4), 529-536.

Mohammed, K. H. (2014). Investigating EFL Learners' Attitudes towards Literature Teaching Methods: Case of 2nd Year LMD Students at the University of Tlemcen (Doctoral dissertation).

Pison, R. (2000) Integrating language and literature: An approach to teaching literary texts. The ACELT Journal, 4(1)

Sell, J. (2005). Why teach literature in the foreign language classroom? Encuentro 15, 86-93.

Shazu, R. I. (2014). Use of literature in language teaching and learning: A critical assessment. Journal of Education and Practice, 5(7), 29-35.

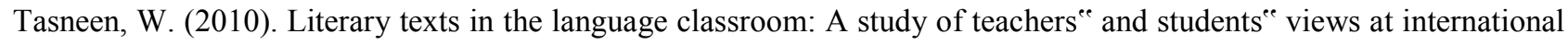
schools in Bangkok. Guest Editors: Wen-chi Vivian Wu and Yu-chuan Joni Chao, 173.

Van, T. T. M. (2009). The relevance of literary analysis to teaching literature in the EFL classroom. In English Teaching Forum (Vol. 47, No. 3). US Department of State. Bureau of Educational and Cultural Affairs, Office of English Language Programs, SA-5, 2200 C Street NW 4th Floor, Washington, DC 20037.

Vural, H. (2013). Use of literature to enhance motivation in ELT classes. Mevlana International Journal of Education, 3(4).

Yopp, R. H. \& Yopp, H. K. (2009). Literature-Based Reading Activities (5th ed.). Boston: Allyn \& Bacon.

Zorba, M. G., Arıkan, A., \& Caner, M. (2013). Prospective English language teachers' views on literature-oriented courses at Akdeniz University's ELT Department. Procedia-Social and Behavioral Sciences, 70, 1847-1851.

\section{Appendix: Attitude toward Literature Survey}

Dear Respondent: This questionnaire is devised with the aim of looking into the current position of English literature in language classes and the probable factors that may influence Iranian language teachers' willingness to utilize literature as an instrument for language learning. To that end, your careful completion of the questionnaire will definitely contribute to obtaining real data which is crucial for more accurate findings. Therefore, please check the box which best describes your opinion. The information will be kept confidential and will be used just for research purposes. Thank you very much in advance for your time and cooperation.

\begin{tabular}{|c|c|c|c|c|c|}
\hline Items & $\begin{array}{ll}\text { Strongly disagree } \\
\text { disagree }\end{array}$ & $\begin{array}{l}\text { Slightly } \\
\text { disagree }\end{array}$ & $\begin{array}{l}\text { Slightly } \\
\text { agree }\end{array}$ & agree & $\begin{array}{l}\text { Strongly } \\
\text { agree }\end{array}$ \\
\hline $\begin{array}{l}\text { 1. Most Iranian language students don't enjoy } \\
\text { reading the literature even in their L1. }\end{array}$ & & & & & \\
\hline $\begin{array}{l}\text { 2. Most Iranian language students don't know any } \\
\text { of the poets and writers of their own culture. }\end{array}$ & & & & & \\
\hline $\begin{array}{l}\text { 3. Most Iranian students can't recite some lines } \\
\text { even from their L1 literature. }\end{array}$ & & & & & \\
\hline $\begin{array}{l}\text { 4. Most Iranian language students don't have any } \\
\text { good memories of their L1 literature classes } \\
\text { and never wish to go back to them. }\end{array}$ & & & & & \\
\hline $\begin{array}{l}\text { 5. Our L1 Persian literature is not welcomed much } \\
\text { by our students. }\end{array}$ & & & & & \\
\hline $\begin{array}{l}\text { 6. Iranian families usually don't pay much } \\
\text { attention to Persian literature. }\end{array}$ & & & & & \\
\hline $\begin{array}{l}\text { 7. Most Iranian language students don't even } \\
\text { exactly know why they should read literature. }\end{array}$ & & & & & \\
\hline $\begin{array}{l}\text { 8. Most Iranian students think reading literature } \\
\text { has no benefit for them. }\end{array}$ & & & & & \\
\hline $\begin{array}{l}\text { 9. Most Iranian language students think that they } \\
\text { may never be able to use literature in their } \\
\text { future life. }\end{array}$ & & & & & \\
\hline $\begin{array}{l}\text { 10. Most Iranian language students think that they } \\
\text { have more important things to read than } \\
\text { literature. }\end{array}$ & & & & & \\
\hline
\end{tabular}


11. No one has ever talked to most Iranian language students on the advantages of reading English literature in enhancing their language knowledge.

12. Most Iranian language students can never find any positive point in reading literature, whether in Persian or English.

13. Most Iranian language students don't read much English poems or storybooks because the English books are very expensive.

14. Most Iranian students don't enjoy reading English literature because they don't like the appearance of the books and their paper qualities.

15. Most Iranian students prefer books coming with audio CDs. If they don't accompany CDs, they may not be interested to buy them.

16. I think some learners don't enjoy literature because the texts are not adapted to their age and proficiency level.

17. Most Iranian students hate literature.

18. Students may get stressed when reading an English poem or story.

19. Sometimes some students may feel depressed after reading stories or poems, so they prefer not to read them.

20. English literary texts are very difficult and complex for most Iranian students and finding all those vocabulary is much tiring and boring for them.

21. It's just a matter of habit. I think the students are not much interested in English literature as a source to improve their English because their teachers never tried so and there was no force on them.

22. I think the teachers' attitude toward literature has an important effect on its range of application by the teachers.

23. Most teachers think using literature in classes is just a waste of time.

24. In most teachers' opinion, the students may not benefit much from reading literary works to improve their English.

25. The reason why most teachers don't use literature in their English classes is that they themselves don't know much about the literature and English writers or poets.

26. Teachers don't use literature in their language classes because they may just hate literature.

27. Some teachers don't use much literature in their classes because they feel they're not that competent in general English to teach it.

28. Most Iranian language teachers don't use much literature in their classes because the students don't enjoy it much.

29. One reason for teachers' lack of willingness to teach literature in their language classes is the negative feedback they receive from the learners.

30. It seems that most students don't cooperate with teachers in studying literature.

31. Iranian language students think that reading literature in language classes is a tough work. 
32. Language students don't have the required time to enhance their general language skills through literature.

33. The time of classes doesn't allow most teachers to take advantage of literature in their language classes.

34. Due to low salaries and other financial issues, most language teachers are not much interested in teaching English literature in their language classes.

35. Most of the time, the limiting policies of the language institutes don't allow teachers to be flexible in their syllabi and use literature in their classes.

36. Most language institutes prohibit teachers from using any kind of handouts (such as story books, poems ...).

37. Language teachers are usually required to only focus on the main book to be taught in the course.

\section{Background:}

1. University Degree:

2. Major:

3. Gender:Male

Female $\square$

4. Age:

5. Years of teaching experience: 